Nurbaiti, N., Wahyuni, Rizki M., \& Nisa H. (2019). Pandangan masyarakat terhadap pelaksanaan hukuman cambuk di Aceh. Indigeneous: Jurnal Ilmiah Psikologi 4(2), 97-105. https://doi.org/10.23917/indigenous.v4i2.6482.

\title{
Pandangan Masyarakat Terhadap Pelaksanaan Hukuman Cambuk di Aceh
}

\author{
Nurbaiti ${ }^{1}$, Wahyuni ${ }^{2}$, Makbull Rizki ${ }^{3}$, Haiyun Nisa ${ }^{4}$ \\ Program Studi Psikologi, Fakultas Kedokteran, Universitas Syiah Kuala1234 \\ nurbaitibetty5@gmail.com¹, wyuni430@yahoo.com², maqbulrizky@gmail.com³, \\ haiyunnisa@unsyiah.ac.id ${ }^{4}$
}

\begin{abstract}
Whip punishment as a form of punishment set out in the jinayah Qanun gets mixed views from all societies that can be analyzed in psychology studies. People's perceptions are strongly influenced by the information received, the knowledge and understanding they have, and the experience of the caning that will affect people's behavior. This study uses a qualitative approach with observation and interview techniques and focus group discussions. The respondents of this research are people from 3 (three) areas in Banda Aceh City with 31 people. The results show that the process of caning is something that can provide the stimulus and learning impact to prevent the occurrence of violations of Islamic Shariah although necessary some reviews and practices in the field as the provisions set forth in Qanun Jinayat. The results of this study can be a recommendation to the government and parties related to the implementation of whip punishment.
\end{abstract}

Keywords: jinayah Qanun; perception; whip punishment

Abstrak. Hukuman cambuk sebagai salah satu bentuk hukuman yang ditetapkan dalam Qanunjinayah mendapatkan pandangan yang beragam dari seluruh masyarakat yang dapat dianalisis dalam kajian psikologi. Pandangan yang beragam ini sangat dipengaruhi oleh informasi yang diterima, pengetahuan dan pemahaman yang dimiliki, serta pengalaman terhadap hukuman cambuk yang akan berpengaruh terhadap perilaku masyarakat. Penelitian ini menggunakan pendekatan kualitatif dengan teknik observasi dan wawancara dan diskusi kelompok terarah. Responden penelitian ini adalah masyarakat yang berasal dari 3 (tiga) wilayah di Kota Banda Aceh sejumlah 31 orang. Hasil penelitian menunjukkan bahwa proses pelaksanaan hukuman cambuk merupakan sesuatu hal yang dapat memberikan rangsangan dan dampak pembelajaran untuk mencegah terjadinya pelanggaran syariat Islam walaupun diperlukan beberapa tinjauan dan praktik di lapangan sebagaimana ketentuan yang telah ditetapkan di dalam Qanun Jinayat No. 6 Tahun 2014. Hasil penelitian ini dapat menjadi rekomendasi terhadap pemerintah dan pihak-pihak terkait pelaksana hukuman cambuk.

Kata Kunci: hukuman cambuk; pandangan; Qanun jinayat

\section{PENDAHULUAN}

Provinsi Aceh merupakan daerah yang menerapkan syari'at Islam dalam pelaksanaan tatanan kehidupan bermasyarakat. Pelaksanaan syari'at Islam diatur secara legal dalam Undang-Undang No. 44 Tahun 1999 tentang Penyelenggaraan Keistimewaan Aceh (bidang agama, adat, pendidikan dan peran ulama dalam penetapan kebijakan daerah), yang diperkuat dengan UU No. 18 tahun 2001 tentang Otonomi Khusus dan Undang-Undang No. 11 Tahun 2006 tentang Pemerintahan Aceh (Dinas Syari'at Islam Aceh, 2015).

Pada pasal 125 UU No. 11 Tahun 2006, disebutkan bahwa proses pelaksanaan syari'at Islam diatur melalui peraturan daerah yang kemudian disebut dengan istilah Qanun. 


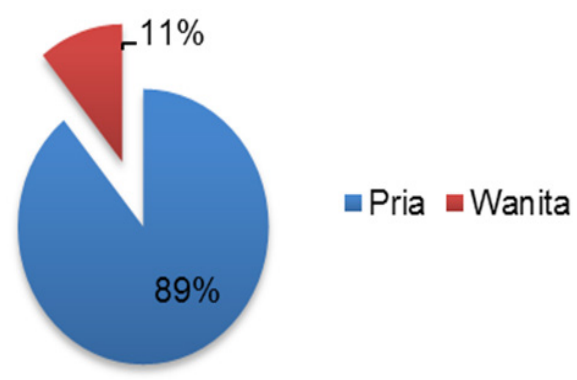

\section{Gambar 1. Data Terpidana Pelanggaran Syariat Islam Berdasarkan Jenis Kelamin Tahun 2016}

Penyusunan Qanun disusun berlandaskan pada asas islami /keislaman dan tidak bertentangan dengan syari'at Islam. Pemerintah Aceh telah mengesahkan beberapa Qanun terkait proses pelaksanaan syari'at Islam di Aceh, yaitu Qanun Provinsi Aceh No. 5 Tahun 2000 tentang pelaksanaan syari'at Islam. Qanun No. 12 Tahun 2003 tentang Minuman Khamar dan sejenisnya, Qanun No. 13 Tahun 2003 tentang Maisir (Perjudian) dan Qanun No. 14 Tahun 2003 tentang Khalwat (Perbuatan Mesum).

Ada beberapa ketentuan terkait pelaksanaan syari'at Islam dalam UU No. 11 Tahun 2006 dalam Pasal 125 yang berbunyi: (1). Syari'at Islam yang dilaksanakan di Aceh meliputi aqidah, syari'ah dan akhlaq; (2). Syari'at Islam sebagaimana dimaksud pada ayat (1) meliputi ibadah, ahwal al-syakhsyiyah (hukum keluarga), muamalah (hukum perdata), jinayat (hukum pidana), qadha' (peradilan), tarbiyah (pendidikan), dakwah, syiar dan pembelaan Islam.

Berbagai pandangan yang sifatnya kontradiktif atas pengesahan Qanun No. 6 Tahun 2014 menimbulkan dilematika dalam proses penegakannya. Sebagian masyarakat mengganggap dan cenderung khawatir bahwa pemberlakuan Qanun tersebut hanya untuk golongan "kecil", sebagaimana cerminan atas keberlakuan Qanun sebelumnya. Qanun Jinayat juga dianggap sebagai diskriminasi dan pelanggaran hak asasi (Fadlia, F., \& Ramadani, 2018). Hal tersebut turut serta menimbulkan dinamika dalam masyarakat yang cenderung kurang mengerti akan tujuan disahkannya Qanun No. 6 Tahun 2014 tersebut.

Qanun No. 6 Tahun 2014 diatur jenis jinayah berikut dengan sanksi yang diberikan kepada para pelanggar. Asas yang dianut dalam pelaksanaan hukum jinayat mencakup (a). keislaman; (b). legalitas; (c). keadilan dan keseimbangan; (d). kemaslahatan; (e). perlindungan hak asasi manusia; (f). Pembelajaran kepada masyarakat (tadabbur). Adapun cakupan jenis jinayat yang terdapat dalam Qanun tersebut adalah: (a). khamar; (b). maisir; (c). khalwat; (d). ikhtilath; (e). Zina; (f). Pelecehan seksual; (g). pemerkosaan; (h). Qadzaf; (i). Liwath; dan (j). Musahaqah. Adapun bentuk hukuman yang akan diberikan kepada pihak yang melakukan pelanggaran terhadap syari'at Islam adalah hukuman cambuk; denda berupa emas atau penjara (Mahdi, 2011). Banyaknya cambuk atau denda ditentukan oleh tingkat kesalahan yang dilakukan oleh para pelanggar syari'at Islam. Paling ringan sepuluh kali atau denda 100 gram

Tabel 1. Data Jumlah Pelanggaran Syariat Islam Berdasarkan Kasus

\begin{tabular}{cccc}
\hline $\begin{array}{c}\text { Bentuk } \\
\text { Pelanggaran }\end{array}$ & $\begin{array}{c}\text { Jenis Kelamin Terpidana } \\
\text { Wria }\end{array}$ & Wanita & Total \\
\hline Maisir & 259 & 2 & 261 \\
Khamar & 7 & 2 & 27 \\
Khalwat & 11 & 9 & 20 \\
Mesum & 10 & 11 & 21 \\
Ikhtilath & 7 & 7 & 14 \\
Zina & 6 & 6 & 12 \\
Pencabulan & 2 & 0 & 2 \\
Total & 302 & 37 & 339 \\
\hline
\end{tabular}


emas atau penjara 10 bulan dan paling berat adalah 150 kali atau denda 1.500 gram emas atau penjara 150 bulan (Ulya, 2016)

Proses hukuman cambuk sebagai salah satu bentuk penerapan Qanun Jinayat memberikan pandangan dan penilaian yang beragam. Hukuman cambuk ini juga banyak menuai pro dan kontra di berbagai kalangan baik akademisi, praktisi maupun masyarakat biasa. Hal ini tidak hanya muncul di daerah, tetapi juga menjadi permasalahan nasional bahkan internasional. Penerapan hukuman cambuk diharapkan mampu mengurangi terjadinya pelanggaran syari'at Islam di Aceh, namun pelaksanaan hukuman cambuk menimbulkan reaksi yang berbeda-beda pada masyarakat. Respon inilah yang kemudian membentuk persepsi atau pandangan dan penilaian terhadap suatu objek atau peristiwa. Penolakan dan pertentangan terhadap pembelakuan Qanun Jinayah di Aceh karena banyak pihak belum memahami dengan benar tentang hukum jinayah, tujuan penghukuman dan ketertiban serta syari'at yang ingin diwujudkan dengan hukum jinayah. Konstruksi hukum yang sedang dalam proses ini diupayakan untuk memenuhi kebutuhan masa depan yang semakin rumit dan kompleks, serta tidak tersandung pada tuduhan mengabadikan hak asasi manusia (HAM) dan kesetaraan gender (Dinas Syari'at Islam Aceh, 2015). Bagi masyarakat dan pemerintah Aceh, penerapan hukum bagi pelanggar syari'at Islam merupakan jalan agar terwujudnya kedamaian, ketenangan, kebahagian dan keselamatan hidup di dunia dan akhirat.

Paparan di atas menjadi landasan peneliti untuk melakukan penelitian yang berkaitan dengan dengan pandangan dan persepsi masyarakat terhadap proses dan pelaksanaan hukuman cambuk di Banda Aceh. Hukuman cambuk merupakan hukuman yang diberikan kepada individu muslim yang melakukan pelanggaran syari'at Islam di Aceh yang telah diatur dengan Qanun Jinayah

\section{METODE PENELITIAN}

Kajian ini menggunakan metode pene- litian kualitatif bersifat fenomenologis dengan teknik pengumpulan data observasi, wawancara. Penelitian kualitatif menekankan pada dinamika dan proses yang terjadi (Poerwandari, 1998). Penelitian ini juga secara khusus menggunakan metode narasi, yang merupakan interpretasi terorganisir atau sekuensi peristiwa. Menurut (Murray, 2008), bentuk penelitian narasi merupakan suatu laporan yang menata ulang cerita dari narasumber sehingga menjadi lebih tertata dan sistematis, sehingga terdapat struktur yang jelas dari awal, tengah dan akhir dari berbagai informasi yang didapatkan. Metode penelitian narasi ini, peneliti dapat mengeksplorasi dan menginterpretasi temuan dengan pemahaman yang komprehensif atas kejadian dan pengalaman yang dialami oleh responden penelitian (Crossley, 2000). Banister (dalam Poerwandari, 1998) menjelaskan penelitian kualitatif merupakan pendekatan yang dilakukan dengan jumlah kasus sedikit dan berfokus pada kedalaman dan proses.

Teknik pengumpulan data dilakukan dengan wawancara yang merupakan aktivitas tanya jawab yang diarahkan untuk mencapai tujuan tertentu. Proses wawancara dilakukan dengan para akademisiyang merupakan perumus Qanun Jinayah sebagai asesmen awal untuk mengetahui proses dan dasar penyusunan serta pemberlakuan Qanun jinayah di Aceh. Hasil wawancara tersebut digunakan sebagai pedoman diskusi kelompok terarah pada masyarakat umum. Kelompok terarah adalah suatu tipe kelompok tertentu dalam arti tujuan, besarnya, komposisinya, dan prosedurnya. Tujuan kelompok ini adalah untuk mengumpulkan pendapat suatu kelompok mengenai suatu hal. Kelompok terdiri atas beberapa individu yang mempunyai karakteristik tertentu. Responden penelitian ini terdiri dari 31 orang masyarakat dalam wilayah kota Banda Aceh yang dibagi dalam 3 (tiga) kelompok diskusi terarah. Proses dalam pelaksanaan diskusi kelompok terarah, individu atau peserta diskusi diberikan kesempatan untuk menceritakan kejadian dan pengalaman masyarakat terhadap proses pelaksanaan hukuman cambuk. Hasil dari wawancara dicatat dalam bentuk narasi dan 
Tabel 2. Tema-Tema Hasil Penelitian

\begin{tabular}{cl}
\hline No. & Tema-Tema Hasil Penelitian \\
\hline 1. & Pengetahuan dan pemahaman tentang terbentuknya Qanun Jinayat. \\
2. & Sosialisasi Qanun Jinayat \\
3. & Reaksi dan tanggapan masyarakat \\
4. & Peran komunitas dalam proses penerapan qanun jinayah \\
5. & Stigma/Label bagi pelanggar \\
6. & Rehabilitasi terpidana hukuman cambuk \\
7. & Harapan masyarakat terkait pelaksanaan hukuman cambuk \\
\hline
\end{tabular}

diperinci dalam bentuk cerita.

Penggunaan metode narasi bertujuan untuk memperoleh pemahaman yang komprehensif atas kejadian dan pengalaman yang dialami oleh responden. Informasi dari peristiwa yang dialami atau dimaknai oleh responden dianalisis secara sekuensial untuk mendapatkan informasi yang menyeluruh dan berarti. Informasi yang diperoleh dari responden penelitian ini adalah proses terbentuknya Qanun Jinayat dan penerapannya, reaksi dan tanggapan masyarakat, pro dan kontra penerapan Qanun Jinayat, hambatan serta harapan akan proses hukuman cambuk sebagai salah satu bentuk penerapan Qanun jinayat.

\section{HASIL DAN PEMBAHASAN}

Metode observasi dan wawancara yang digunakan dalam penelitian ini menghasilkan catatan observasi, verbatim wawancara serta notulensi dari diskusi terarah. Hasil penelitian ini selanjutnya dikategorisasi dalam tema-tema yang muncul saat wawancara dan diskusi kelompok terarah. Proses kategorisasi ini dilakukan secara bersama-sama oleh tim peneliti yang sesuai dengan tujuan penelitian. Beberapa tema yang dihasilkan dari kategorisasi dapat dilihat pada Tabel 2 .

Pengetahuan dan pemahaman mengenai hukuman cambuk dan Qanun Jinayat

Aceh memiliki keistimewaan dalam proses pelaksanaan syari'at Islam. Keistimewaan ini diatur dalam Undang-Undang Hukuman cambuk merupakan salah satu bentuk hukuman yang berlaku dalam regulasi penerapan Qanun Jinayat. Qanun Jinayat merupakan aturan hu- kum yang berlaku untuk pelaksanaan syari'at Islam di Aceh. Penerapan Qanun jinayat dipandang belum cukup dipahami oleh masyarakat, perlu dilakukannya sosialisasi dan pemberian informasi yang berkelanjutan, sehingga seluruh masyarakat dapat mengetahui dan memahami mengenai penerapan Qanun jinayat.

"Ya kami hanya tahu bahwa kalau pelanggar syari'at Islam ya akan dihukum cambuk, kami kurang mengetahui hal-hal lainnya.".

\section{Efek jera dan pencegahan pelanggaran syari'at islam}

Hukuman cambuk yang diberlakukan memiliki tujuan salah satunya adalah memberikan efek jera baik kepada pelanggar maupun kepada seluruh masyarakat agar tidak melakukan sesuatu yang dapat melanggar syari'at Islam.

"Ya kami berharap dengan adanya hukuman cambuk, orang-orang menjadi takut untuk melakukan pelanggaran, sehingga tidak ada lagi nanti orang yang akan dihukum cambuk."

\section{Reaksi dan tanggapan masyarakat}

Hukuman cambuk yang berlaku di Aceh memberikan warna tersendiri dalam tatanan kehidupan masyarakatnya. Pemberlakuan hukuman cambuk dimaknai dengan cara yang beragam. Ada sebagian masyarakat yang cenderung tidak ingin menyaksikan secara langsung proses eksekusi hukuman cambuk karena akan mengingatkannya jika hukuman cambuk tersebut terjadi pada dirinya atau keluarganya.

"Kami tidak mau menyaksikan secara langsung proses hukuman cambuk, karena kami sedih, kami ingat anak cucu sendiri. 
Kami kasian dengan orang-orang yang dihukum cambuk, kadang-kadang yang dihukum cambuk adalah anak rantau yang cari ilmu kesini, melanggar syariat dan dibukum cambuk", Kami juga tidak setuju, kenapa harus dibuat di mesjid, mereka kan jadi malu, kasian mereka."

\section{Keadilan dan konsistensi dalam penegakan hukuman}

Masyarakat mengharapkan adanya keadilan dalam penegakan hukum terhadap pelanggar syari'at Islam. Berdasarkan informasi, terkadang terjadi ketidakadilan dalam proses penegakan hukuman bagi pelanggar syari'at Islam. Masyarakat menilai bahwa dalam penerapan Qanun jinayat ini ada kecenderungan penegakan hukum yang tajam ke bawah dan tumpul ke atas, sehingga masyarakat merasa bahwa ada ketidakadilan dalam proses pelaksanaan hukuman.

"Nah, satu lagi kurangnya dalam proses penerapan Qanun jinayat, ada kecenderungan kalau anak pejabat itu terkadang beritangnya jadi hilang, terus tidak dicambuk. Ini perlu diperhatikan sebagai koreksi bagi pemerintah".

\section{Dampak proses hukuman cambuk yang dilakukan di depan umum bagi anak}

Proses eksekusi hukuman cambuk yang dilakukan di halaman mesjid dinilai beragam oleh masyarakat. Ada yang menganggap bahwa eksekusi di halaman mesjid akan membuat membuat malu terpidana sehingga tidak akan melakukan pelanggaran lagi nantinya.

"Bagi terpidana pelanggaran syariat Islam yang dihukum cambuk di halaman mesjid akan memberikan rasa malu, sehingga tidak lagi akan melakukannya.”.

Proses eksekusi hukuman cambuk yang telah dijalankan memberikan ruang dan kebebasan kepada semua lapisan masyarakat untuk menyaksikannya secara langsung termasuk anak-anak. Hasil observasi menunjukkan walaupun petugas keamanan telah melarang secara verbal agar anak-anak tidak berada di wilayah / lokasi pencambukan, namun masih terdap- at anak-anak yang dapat menyaksikan proses hukuman cambuk dari luar lokasi mesjid yang tidak diawasi oleh petugas keamanan. Perkembangan anak sebaiknya menjadi perhatian para pihak dalam proses impelementasi hukuman cambuk tersebut.

"Anak-anak banyak yang melihat proses hukuman cambuk dan menirukan kembali proses hukuman cambuk yang telah dilaksanakan. Walaupun terlihat seperti bermain peran, tetapi hal tersebut dapat mempengaruhi perkembangan anak".

\section{Rehabilitasi bagi terpidana yang dihukum cambuk}

Hukuman cambuk yang dijatuhkan kepada para pelanggar syari'at Islam tentu akan berdampak pada kehidupannya, baik jangka pendek maupun jangka panjang. Proses hukuman cambuk yang hanya berlangsung selama $1 \mathrm{x}$ juga akan memberikan warna yang berbeda dalam kehidupannya. Qanun Jinayat, didalamnya telah diatur mengenai rehabilitasi, tetapi pelaksanannya belum berjalan dengan baik. Setelah seorang pelanggar dihukum cambuk, maka selanjutnya langsung dikembalikan kepada keluarganya.

\section{Peran keluarga}

Pelaksanaan syari'at Islam dan penerapan Qanun jinayat akan berjalan dengan efektif dengan keterlibatan dan peran dari keluarga. Keluarga merupakan garda utama yang dapat berperan preventif terhadap terjadinya pelanggaran syari'at Islam. Peran dan kontribusi keluarga merupakan hal yang sangat penting sehingga akan dapat mencegah terjadinya pelanggaran syari'at Islam.

"Keluarga harus mengetahui apa yang dilakukan oleh anggota keluarganya terutama di luar rumah, dan anggota keluarga perlu diinformasikan hal-hal yang dilarang oleh agama sejak dini, sehingga anggota keluarga tidak akan melakukan pelanggaran syari'at Islam.".

Masyarakat memiliki pandangan yang beragam terhadap proses pelaksanaan hukuman cambuk. Pandangan yang bervariasi ini 
akan mempengaruhi dinamika perilaku masyarakat baik kepada terpidana, terhadap proses hukuman cambuk dan penerapan Qanun jinayat pada umumnya. Menurut (Muzakkir, Thaib, Suhaidi, \& Abdullah, 2017) persepsi dari masyarakat yang beragam dan merespon bahwa tidak ada yang menginginkan implementasi Syariat Islam secara menyeluruh yang mencakup semua dimensi kehidupan menjadi tantangan dalam pelaksanaanya hukuman cambuk. Respon, pandangan yang beragam inilah yang kemudian disebut sebagai persepsi, yang mana individu akan merespon stimulus yang diterimanya dan selanjutnya informasi tersebut akan diinterpretasi berdasarkan pengetahuan dan pengalaman yang dimilikinya.

Berbagai respon dan reaksi dari masyarakat baik bersifat pro dan kontra dipengaruhi oleh beberapa hal seperti banyaknya para pihak yang belum memahami dengan benar hakikat hukum jinayat, tujuan penghukuman dan ketertiban serta syari'at yang ingin diwujudkan dengan penegakan hukum jinayat.

Beragamnya pandangan dan persepsi masyarakat terhadap hukuman cambuk dipengaruhi oleh beberapa hal, yaitu pengetahuan dan pemahaman masyarakat terhadapat pelaksanaan syari'at Islam, penerapan Qanun jinayat dan hukuman cambuk. Hal ini sesuai dengan yang dikemukakan oleh (Ancok \& Suroso, 1995) yang menyatakan bahwa pengetahuan merupakan salah satu hal yang sangat penting dalam pembentukan sikap, baik itu sikap positif maupun negatif.

Hal lainnya yang juga mempengaruhi adalah cara individu untuk mendapatkan pengetahuan, mengolah dan menerjemahkannya berdasarkan kebenaran dari pengetahuan itu sendiri. Pengetahuan merupakan proses belajar yang dapat memengaruhi individu yang dapat bersumber dari keluarga, masyarakat dan media massa yang sangat efektif sebagai model perilaku yang terus berulang dan menjadi faktor penguat (Myers, 2012).

Hal ini sejalan dengan informasi yang diperoleh dari responden penelitian bahwa sosialisasi mengenai pelaksanaan syari'at Islam perlu terus menerus dilakukan dengan berbagai alternatif media, baik secara langsung maupun melalui media lainnya. Keluarga dan lingkungan memiliki peran penting dalam proses penyampaian informasi terkait pelaksanaan syari'at Islam terutama tentang hukuman cambuk bagi para pelanggar Qanun jinayat. Pemerintah juga memiliki tanggung jawab untuk memberikan pemahaman kepada masyarakat (Ulya, 2016).

Pelaksanaan hukuman cambuk bagi para pelanggar Qanun jinayat dinilai dapat memberikan efek jera bagi pelanggar dan juga orang yang mengetahui tentang hal tersebut. Klaim yang mengatakan bahwa hukum cambuk merupakan penyiksaan adalah tidak tepat (Muhammadin, F. M., Wicaksono, Sari, \& Ayutama, 2018). Efek jera tersebut memberikan penurunan terhadap angka pelanggar syari'at Islam karena terpidana menyesal atas perbuatannya dan merasa malu dihukum didepan umum (Danial, 2012). Hukuman cambuk akan menimbulkan rasa malu bagi terpidana, karena pidana badan dilaksanakan di tempat umum sehingga diketahui orang banyak juga menjadi pelajaran bagi masyarakat yang menyaksikan (Hartanto, 2016).

Hukuman cambuk yang diberlakukan pada para pelanggar memberikan dampak tersendiri yang dapat mempengaruhi kondisi psikologisnya. Adanya tantangan dalam implementasi syariah oleh pemerintah di Aceh dan pengalaman hidup terpidana (Taylor, 2015). Hal ini memerlukan perhatian para pihak, yaitu pemulihan dan rehabilitasi psikologi. Kenyataannya, proses pemulihan dan rehabilitasi belum terlaksana walaupun hal tersebut telah tercantum di dalam Qanun jinayat. Pemulihan dan rehabilitasi psikologis dapat membantu individu untuk kembali menjalani kehidupannya secara positif setelah peristiwa yang dialami. Proses integrasi kembali ke keluarga dan masyarakat juga merupakan hal yang sangat penting, sehingga terpidana yang melanggar syari'at tidak akan merasa disingkir dan disisihkan dari kelompok atau komunitasnya sendiri. Hal ini juga dinyatakan oleh (Sutrisno, 2016) yang menyebutkan bahwa penting untuk memastikan kondisi psikologis saat pelanggar kembali ke komunitas, sehingga tidak ada kecenderungan adanya penolakan dari komunitasnya tersebut. 
Implementasi syariat Islam memerlukan peran semua pihak, salah satunya adalah keluarga. Keluarga merupakan pintu pertama yang dapat menjadi filter agar tidak terjadinya pelanggaran syari'at Islam, sehingga dapat mengurangi para terpidana yang akan mengalami hukuman cambuk. Keluarga harus menerapkan pendidikan kepada anak sejak dini, sehingga anak memiliki kesadaran dan tidak akan melakukan pelanggaran syari'at Islam.

Hal ini juga selaras dengan penelitian yang telah dilakukan oleh (Sutrisno, 2016) yang menyatakan bahwa implementasi syari'at Islam harus diawali dari keluarga dengan harapan bahwa anak-anak akan mampu memiliki kesadaran sejak dini bahwa dalam proses individu memiliki aturan dalam prosesnya menjalani kehidupan.

Berdasarkan hasil penelitian yang telah dilakukan diperoleh hasil bahwa masyarakat memiliki pandangan, persepsi yang beragam terhadap proses hukuman cambuk bagi para pelanggar syari'at Islam di Aceh. Pengetahuan dan pemahaman terhadap hukuman cambuk sangat memengaruhi penilaian masyarakat terhadap objek atau peristiwa tersebut. Pro dan kontra yang terjadi di masyarakat disebabkan oleh kurangnya informasi yang komprehensif terkait proses pelaksanaan hukuman cambuk sebagai penerapan Qanun jinayah. Efek jera dan rasa malu yang dimaksud memberikan proses pembelajaran kepada individu dan masyarakat lainnya agar tidak melakukan pelanggaran syari'at Islam. Masyarakat menganggap bahwa kepedulian masyarakat akan dapat meminimalisir munculnya atau dilakukannya pelanggaran syari'at Islam. Hal ini juga perlu didukung oleh peran keluarga sebagai garda depan yang dapat mencegah terjadinya pelanggaran syari'at Islam. Mekanisme dalam proses eksekusi hukuman cambuk juga merupakan hal penting, sehingga dapat meminimalisir dampak bagi pihak-pihak tertentu terutama anak-anak. Prinsip keadilan dan konsistensi dalam penegakan aturan menjadi fokus yang paling penting sehingga menentukan penilaian masyarakat terhadap penerapan Qanun jinayat.

Angka pelanggaran syari'at Islam akan dapat dicegah dengan peranan dari lingkungan dan komunitas, hal ini sesuai dengan konsep yang dikemukakan oleh (Lewin, 1936) bahwa terjadi interaksi antara individu dan lingkungan dalam menentukan perilaku manusia. Perilaku manusia selalu dikendalikan oleh faktor luar (faktor lingkungannya, rangsangan atau stimulus). (Lewin, 1936) juga berpendapat bahwa tingkah laku manusia merupakan hasil interaksi diri individu dengan lingkungannya, dimana di dalam kehidupan individu tidak akan pernah lepas dari lingkungan tempat dia berada.

Hasil penelitian yang telah dilakukan untuk mengetahui pandangan dan persepsi masyarakat terhadap hukuman cambuk merumuskan beberapa saran, yaitu : (1). Pentingnya sosialisasi komprehensif dan berkesinambungan kepada seluruh lapisan tentang Qanun jinayah; (2). Perlunya diatur mekanisme eksekusi hukuman cambuk, sehingga meminimalisir dampak secara psikologis bagi terpidana dan masyarakat khususnya anak-anak; (3). Perlu dilakukannya rehabilitasi dan pemulihan psikologis bagi para pelanggar sehingga dapat melanjutkan proses hidupnya; (4). Diperlukannya peran keluarga dalam mencegah terjadinya pelanggaran syari'at Islam

\section{SIMPULAN}

Berdasarkan hasil penelitian yang telah dilakukan diperoleh hasil bahwa masyarakat memiliki pandangan, persepsi yang beragam terhadap proses hukuman cambuk bagi para pelanggar syari'at Islam di Aceh. Pengetahuan dan pemahaman terhadap hukuman cambuk sangat memengaruhi penilaian masyarakat terhadap objek atau peristiwa tersebut. Pro dan kontra yang terjadi di masyarakat disebabkan oleh kurangnya informasi yang komprehensif terkait proses pelaksanaan hukuman cambuk sebagai penerapan Qanun jinayah. Efek jera dan rasa malu yang dimaksud memberikan proses pembelajaran kepada individu dan masyarakat lainnya agar tidak melakukan pelanggaran syari'at Islam. Masyarakat menganggap bahwa kepedulian masyarakat akan dapat meminimalisir munculnya atau dilakukannya pelanggaran 
syari'at Islam. Hal ini juga perlu didukung oleh peran keluarga sebagai garda depan yang dapat mencegah terjadinya pelanggaran syari'at Islam. Mekanisme dalam proses eksekusi hukuman cambuk juga merupakan hal penting, sehingga dapat meminimalisir dampak bagi pihak-pihak tertentu terutama anak-anak. Prinsip keadilan dan konsistensi dalam penegakan aturan menjadi fokus yang paling penting sehingga menentukan penilaian masyarakat terhadap penerapan Qanun jinayat.

Angka pelanggaran syari'at Islam akan dapat dicegah dengan peranan dari lingkungan dan komunitas, hal ini sesuai dengan konsep yang dikemukakan oleh (Lewin, 1936) bahwa terjadi interaksi antara individu dan lingkungan dalam menentukan perilaku manusia. Perilaku manusia selalu dikendalikan oleh faktor luar (faktor lingkungannya, rangsangan atau stimulus). (Lewin, 1936) juga berpendapat bahwa tingkah laku manusia merupakan hasil interaksi diri individu dengan lingkungannya, dimana di dalam kehidupan individu tidak akan pernah lepas dari lingkungan tempat dia berada.

Saran yang dapat diberikan berdasarkan hasil penelitian ini adalah: (1) Pentingnya sosialisasi komprehensif dan berkesinambungan kepada seluruh lapisan tentang Qanun jinayah; (2) Perlunya diatur mekanisme eksekusi hukuman cambuk, sehingga meminimalisir dampak secara psikologis bagi terpidana dan masyarakat khususnya anak-anak; (3) Perlu dilakukannya rehabilitasi dan pemulihan psikologis bagi para pelanggar sehingga dapat melanjutkan proses hidupnya; (4) Diperlukan peran keluarga dalam mencegah terjadinya pelanggaran syari'at.

\section{DAFTAR PUSTAKA}

Ablisar, M. (2014). Relevansi hukuman cambuk sebagai salah satu bentuk pemidanaan dalam pembaharuan hukum pidana. Jurnal Dinamika Hukum (2), 278-289

Ancok, D., \& Suroso, F. N. (1995). Psikologi islami: Solusi islam atas problem-problem psikologi. Yogyakarta : Pustaka Pelajar

Crossley, M. L. (2000). Introducing narrative psychology: Self, trauma and the construction of meaning. Buckingham : Open University Press.

Danial. (2012). Qanun jinayah Aceh dan perlindungan HAM (kajian yuridis-filosofis). Jurnal Kajian Hukum Islam, 6(1), 85-98.

Dinas Syariat Islam Aceh. (2015). Hukum jinayat dan hukum acara jinayat. Banda Aceh: Naskah Aceh.

Fadlia, F., \& Ramadani, I. (2018). The Qanun jinayat discriminates against women (victims of rape) in Aceh, indonesia. Journal of Southeast Asian Human Rights, 2(2), 448-470.

Idrus, M. (2009). Metode penelitian ilmu sosial. Yogyakarta: Erlangga.

Hartanto, D. A. (2016). Kontribusi hukum Islam dalam pembaharuan hukum pidana di Indonesia (Studi pidana cambuk di Nanggroe Aceh Darussalam). Al-Abkam: Jurnal Ilmu Syariah dan Hukum, 1(2), 171-192.

Lewin, K. (1936). A dynamic theory of personality. New York: McGraw Hill.

Mahdi. (2011). Sistem hukum penegakan Qanun jinayah di Aceh. Media Syariah, 13(2), 179-192.

Muhammadin, F. M., Wicaksono, D. A., Sari, A. C. F., \& Ayutama, O. A. (2018). Lashing in Qanun aceh and the convention against torture: A critical appraisal. Jurnal Media Syariah, $7(1), 11-24$.

Muzakkir, Thaib, H. Suhaidi. Abdullah, Z. (2017). Implementation of law in Aceh after application Qanun jinayah. International Journal of Humanities and Social Science Invention, 6(9), 
$1-7$.

Myers, D. G. (2012). Psikologi sosial. Terjemahan: Aliya dkk. Jakarta: Salemba Humanika.

Murray, M. (2008). Naratif Psychology. dalam J.A. Smith (Ed.) Qualititative psychology: a practical guide to methode (ed ke-2). London: Sage.

Poerwandari, K. (1998). Pendekatan kualitatif untuk penelitian perilaku manusia. Jakarta: Perfecta Fakultas Psikologi Universitas Indonesia.

Qanun Aceh Nomor 6 Tahun 2014 Tentang Hukum Jinayat.

Sutrisno, I. H. (2016). Case study roles of islamic law in the perspective of sociological the community langsa. Journal of Research in Humanities and Social Science, 4(9), 69-78.

Taylor, R. (2015). Syariah as heterotopia: responses from muslim women in Aceh, Indonesia. Religions, 6(2), 566-593.

Ulya, Z. (2016). Dinamika penerapan hukum jinayah sebagai wujud rekonstruksi syariat Islam di Aceh. Jurnal Rechtsvinding, 5(1), 135-148. 